\title{
The Type A Phages of Salmonella typhimurium: Observations on Temperate Phage and Lysogenesis
}

\author{
By J. S. K. BOYD AND D. E. BIDWELL \\ The Wellcome Laboratories of Tropical Medicine, London, N.W. 1
}

(Received 25 March 1961)

\begin{abstract}
SUMMARY
When a standard suspension of Salmonella typhimurium Q1, an indicator strain sensitive to the type A phages recovered from lysogenic strains of this organism, was exposed to concentrations of these phages giving a phage:bacteria ratio of approximately 1:10 (thus ensuring that, with rare exceptions, bacteria became infected with single phage particles) it was found that definite percentages of the bacteria were either lysogenized or productively infected (lysed). These percentages were constant for each particular phage type, but varied widely in the 11 members of the group. It was concluded that each phage consisted of a mixed population of particles, some capable, as single infections, of producing lysogenization ( $\alpha$ particles) and others lacking this property ( $\beta$ particles). An increase in the phage:bacteria ratio, resulting in multiple infections of single bacteria, led to an increase in lysogenization at the expense of productive infection. The number of $\alpha$ particles present in any particular concentration of phage was calculated from the figures determined at low phage:bacteria ratios (limit dilution). With some phages, when bacteria became infected with more than one particle by exposure to rising phage concentrations, the number lysogenized was compatible with the hypothesis that $\alpha$ particles are dominant over $\beta$ particles, and that every bacterium infected by an $\alpha$ particle is lysogenized. This hypothesis was however invalidated by the fact that, with other phages, either the number of bacteria lysogenized was in excess of the available $\alpha$ particles, indicating that bacteria had been lysogenized by infection with two or more $\beta$ particles, or the number of $\alpha$ particles was grossly in excess of the number of bacteria lysogenized. The implications of these findings are discussed.

Very high concentrations of these temperate phages produced lysis-from-without, and in some cases appeared to induce lysis of bacteria which had first been lysogenized. In all cases in which such experiments were carried out, exposure to low temperatures $\left(20^{\circ}\right)$, to high temperatures $\left(42^{\circ}\right)$, to the salts of certain organic acids, and to anaerobiosis had no significant effect on lysogenization.
\end{abstract}

\section{INTRODUCTION}

The type A phages of Salmonella typhimurium (Boyd \& Bidwell, 1957) have been studied by us over a number of years, and various details of their lysogenizing properties have been observed, some of which are in agreement with accepted ideas, while others are not. As these closely related phages were all isolated from strains of $S$. typhimurium recovered from infected human beings or contaminated food, 
and are therefore members of a natural group, and not artificially produced mutants, the findings are considered of sufficient interest to be placed on record. They may serve to focus attention on the fact that, while remarkable progress has been made in the investigation of the biochemical and biophysical properties and of the genetic aspects of certain 'laboratory' strains of phage, little or no work of a systematic nature has been done in identifying and correlating the phages found, in prophage form, in different species of bacteria. As a consequence, knowledge of bacterial viruses as they occur in nature is fragmentary and elementary, and a vast source of information is virtually untapped.

\section{METHODS}

In general, the materials and methods are those which have been described in previous papers (Boyd, 1950; Boyd \& Bidwell, 1957). The media used were standardized nutrient agar and Lemco broth, though occasionally, in an endeavour to repeat the results of others, the special media recommended by them were employed. The indicator strain used throughout was Salmonella typhimurium Q1 (Boyd, 1956) and the phages were 11 of the 12 types classified by cross-immunity tests (Boyd \& Bidwell, 1957) all of which have been adapted to and are maintained and propagated on Q1. Type A4 was not investigated, as repeated and prolonged attempts have failed to recover from this temperate phage the virulent mutant necessary for the experiments. Concentrated suspensions of phage particles- $10^{11} / \mathrm{ml}$. and overwere prepared by the method described by Liu (1958). All incubations which involved accurate timing were carried out in a Grant waterbath. The EEL nephelometer was used to estimate the turbidity of cultures and suspensions of bacteria. The methods of counting free phage particles in a suspension, which are fundamental to the work, are described in detail in the first part of the paper.

A bacterium is said to be 'lysogenized' when the invading temperate phage is converted to prophage, and 'productively infected' when the phage particle multiplies at the expense of the bacterium to produce a brood of daughter particles. The latter process is for brevity referred to as a 'burst'. Throughout the paper the bacterial indicator is designated $\mathrm{Q} 1$, the different phages $\mathrm{A} 1 a, \mathrm{Al} b$, etc., and the lysogenic bacteria Q1 (A1 $a$ ), Q1 (A $1 b)$, etc. The phage particles of a temperate phage are for convenience differentiated by the symbols suggested in an earlier publication (Boyd, 1953). $\alpha$ particles are those which as single infections of a sensitive bacterium produce lysogenesis. $\beta$ particles are those which, as single infections, produce, not lysogenesis, but a burst. The outcome of such bursts is, of course, a temperate phage-population consisting of both $\alpha$ and $\beta$ particles. Permanent virulent mutants (Boyd, 1951 a) which produce only virulent (lytic) particles (except for an extremely rare back-mutation giving rise to a $\beta$ particle) are designated $\gamma$ particles.

\section{Counts of bacteria}

\section{RESULTS}

\section{Preliminary.observations}

To make a reliable assessment of the multiplicity of infection, i.e. the number of phage particles adsorbed to each bacterium, accurate counts of bacteria and of the phage particles are required. All bacterial cultures contain non-viable organisms in 
numbers which vary according to the technique of preparation. In the experiments recorded in this paper bacterial suspensions were prepared as follows. A nutrient agar slant was inoculated from a stock culture and incubated overnight at $37^{\circ}$. The following morning the required number of tubes of broth was inoculated from this culture and kept for $3 \mathrm{hr}$. at $37^{\circ}$, by which time the organisms were well advanced in the logarithmic phase of growth. These cultures were then pooled and diluted with broth to an opacity shown by previous trials to contain approximately $10^{8}$ viable bacteria/ml. when further diluted with $1 / 10$ of its volume of broth or phage concentrate. In every experiment a control count of viable bacteria was carried out.

Using suspensions prepared in this way, counts of all the bacteria, viable and nonviable, were made by means of a Thoma haemocytometer, $0.02 \mathrm{~mm}$. in depth, while counts of viable bacteria were calculated from colony counts on agar plates which had been flooded with $0.5 \mathrm{ml}$. of a diluted suspension. The results, shown in Table 1,

Table 1. Comparison of total counts and viable counts of bacterial suspensions

\begin{tabular}{|c|c|c|c|c|}
\hline Expt. & $\begin{array}{l}\text { Total bacteria* } \\
\text { per ml. }\end{array}$ & $\begin{array}{c}\text { Viable bacteria } \uparrow \\
\text { per ml. }\end{array}$ & $\%$ viable & $\begin{array}{c}\% \\
\text { non-viable }\end{array}$ \\
\hline 1 & $1.9 \times 10^{8}$ & $1.04 \times 10^{8}$ & $\mathbf{5 2 \cdot 5}$ & $47 \cdot 5$ \\
\hline 2 & $2.5 \times 10^{8}$ & $1.45 \times 10^{8}$ & $57 \cdot 5$ & $42 \cdot 5$ \\
\hline 3 & $1.74 \times 10^{8}$ & $9.9 \times 10^{7}$ & $57 \cdot 0$ & $43 \cdot 0$ \\
\hline 4 & $1.32 \times 10^{8}$ & $9.2 \times 10^{7}$ & $69 \cdot 0$ & $31 \cdot 0$ \\
\hline 5 & $1.51 \times 10^{8}$ & $9 \cdot 1 \times 10^{7}$ & $60 \cdot 0$ & $40 \cdot 0$ \\
\hline 6 & $1.47 \times 10^{8}$ & $1.04 \times 10^{8}$ & $70 \cdot 0$ & $30 \cdot 0$ \\
\hline 7 & $1.57 \times 10^{8}$ & $1.17 \times 10^{8}$ & $74 \cdot 0$ & $26 \cdot 0$ \\
\hline 8 & $1.51 \times 10^{8}$ & $1.05 \times 10^{8}$ & $69 \cdot 0$ & $31 \cdot 0$ \\
\hline 9 & $1.79 \times 10^{8}$ & $1 \cdot 14 \times 10^{8}$ & 64.0 & $36 \cdot 0$ \\
\hline Average & $1.7 \times 10^{8}$ & $1.08 \times 10^{8}$ & $63 \cdot 5$ & $36 \cdot 5$ \\
\hline
\end{tabular}

* Total counts were made by means of a Thoma haemocytometer, $0.02 \mathrm{~mm}$. in depth, using dark-field illumination.

$\dagger$ Viable counts were made from suitable dilutions of the bacterial suspension flooded in $0.5 \mathrm{ml}$. quantities over the surface of at least 3 plates of nutrient agar.

reveal the fact that roughly one-third of the bacteria are non-viable. It is not possible to separate viable and non-viable bacteria in order to assess their respective adsorptive properties, but it may be assumed that the adsorptive capacity of nonviable bacteria will not differ greatly from that of bacteria killed by minimal heat. In Table 2 the adsorption of phage by a living culture is compared with that of a culture heated to $\mathbf{5 8 \cdot 5 ^ { \circ }}$ for $30 \mathrm{~min}$. There is little significant difference. The slightly decreased adsorption shown by the dead bacteria may be explained by the fact that they are non-motile and hence may have made slightly fewer collisions with the phage particles. This suggests that viable and non-viable bacteria in a culture are likely to have similar adsorptive properties.

The presence of relatively large numbers of non-viable bacteria in the suspensions used in the experiments to be described does not in fact vitiate the results. As identical suspensions were used in counting the phage particles, it follows that an equivalent proportion (approximately one-third) of the phage particles were 'lost' in the counting process by becoming adsorbed to non-viable bacteria. The phage: bacteria ratio and similar calculations are therefore correct when given in terms of the viable bacteria in a suspension, provided a suspension prepared in the same way was used in counting the phage particles. The total bacterial count and 
the total phage count are in fact half as much again as the figures indicate, but this can be disregarded, for both sides of the equation are equally affected. The practical point which emerges is that each experiment on lysogenization or lysis must be controlled, not by a total count of bacteria by whatever means calculated, but by a count of the viable bacteria in the suspension used in the particular experiment.

\section{Method of counting virulent $(\gamma)$ phage particles}

Phage particles which develop only by the 'productive' or lytic cycle, and do not produce lysogenesis, were counted, not by the usual pour-plate method (Hershey, Kalmanson \& Bronfenbrenner, 1943, slightly modified by Adams, 1959), but by the

\section{Table 2. Comparison of the adsorptive properties of living and heat-killed suspensions of $Q 1$}

The bacterial culture gave a count of viable organisms of approximately $10^{8} / \mathrm{ml}$. Phage was added to give the ratios indicated, and the mixtures incubated for $15 \mathrm{~min}$. at $87^{\circ}$. Thereafter the mixtures were at once diluted to prevent further adsorption, the living bacteria killed by heating to $70^{\circ}$ for $30 \mathrm{~min}$. and counts made of the plaque-forming free phage particles.

Phage: bacteria ratio

Percentage of phage particles
adsorbed by $\left\{\begin{array}{c}\text { Culture of living bacteria } \\ \text { Bacteria killed by heating } \\ \text { to } 58 \cdot 5^{\circ} \text { for } 30 \text { min. }\end{array}\right.$
$15: 1$

$67 \cdot 5$

$65 \cdot 5$
$1 \cdot 5: 1$ 94

92

$0 \cdot 15: 1$

$98 \cdot 3$

$95 \cdot 2$

Table 3. Comparison of plaque-counting techniques

Decimal dilutions of concentrated phage Al $b$ were counted by three methods. Each figure in the table is an average of 2 counts. The surface count, measuring drops with the Agla micrometer syringe, is consistently higher than Adams's pour-plate method using $0.7 \%$ agar for the 'layer'. The third method, using $1.2 \%$ agar, gives an even lower count and shows that, the greater the viscosity of the agar, the greater is the loss caused by the mixture sticking to the tube from which it is poured.

\begin{tabular}{|c|c|c|}
\hline \multirow[t]{2}{*}{$\begin{array}{l}\text { Surface } \\
\text { count }\end{array}$} & $\begin{array}{c}\text { Adams's } \\
\text { pour-plate } \\
(0 \cdot 7 \% \text { agar } \\
\text { layer })\end{array}$ & \multirow[t]{2}{*}{$\begin{array}{c}\text { Pour-plate } \\
\text { (1.2\% agar } \\
\text { layer) }\end{array}$} \\
\hline & Plaques/ml. & \\
\hline $.25 \times 10^{11}$ & $1.0 \times 10^{11}$ & $8.1 \times 10^{10}$ \\
\hline $1.23 \times 10^{10}$ & $1.17 \times 10^{10}$ & $8.15 \times 10^{9}$ \\
\hline $1.21 \times 10^{9}$ & $1.02 \times 10^{9}$ & $9.0 \times 10^{8}$ \\
\hline $1.28 \times 10^{8}$ & $1.24 \times 10^{8}$ & $8.55 \times 10^{7}$ \\
\hline
\end{tabular}

surface-count method (Boyd, 1950). After a preliminary rough titration, the phage concentrate was accurately diluted to a point where it contained, in terms of the preliminary titration, $10^{3}$ particles/ml., and, with an Agla micrometer syringe, 5 drops of exactly $0.01 \mathrm{ml}$. of this diluted concentrate were placed at different points on a 'lawn' of Q1 (i.e. the dried surface of a $10 \mathrm{~cm}$. Petri dish of nutrient agar previously flooded with a broth culture of Q1). The drops were spread, but not to the point of coalescence, by gently rocking the plate, which was then incubated overnight. In the morning the plaques were counted, and from this count, multiplied by the appropriate figure to correct the dilution, the number of particles in the original concentrate was calculated. This method is simpler and quicker than the pour-plate method, and gives counts which are about $10 \%$ higher (Table 3 ). This is 
because, in the pour-plate method, bacteria and phage are mixed with soft agar in a tube before being poured on to a plate of agar of normal consistency. Inevitably some of the agar mixture sticks to the sides of the test tube, and so is lost to the count, whereas when using the Agla syringe, a drop of the exact size is ejected from the square-cut needle without loss.

\section{Method of counting temperate phage particles}

When bacteria are mixed with temperate phage diluted to such an extent that each organism is infected by only one phage particle, the infected bacteria are either rendered lysogenic (by $\alpha$ particles) or are productively infected (by $\beta$ particles). If such a phage-bacteria mixture, suitably diluted, is spread on a lawn of indicator bacteria, the productively infected bacteria will produce turbid plaques of normal size, but, as will be seen later, only a relatively small number of the lysogenized bacteria will produce plaques, most of which will be of small size. To make an accurate count it is therefore necessary to use a technique which will reveal both lysogenized and productively infected bacteria.

The $\alpha$ particles in a temperate phage were counted as follows. A preliminary count of the plaque-forming particles was made by the method just described for $\gamma$ particles. (For convenience this preliminary count of a temperate phage, which is used as a starting point in certain of the experiments, is called a plaque count. In a high-titre concentrate the plaque count was approximately $10^{11} / \mathrm{ml}$.) The concentrate was then accurately diluted to give $10^{8}$ plaque-forming particles $/ \mathrm{ml}$. One $\mathrm{ml}$. of this dilution was added to $9 \mathrm{ml}$. of a suspension of $Q 1$, giving a final count of $10^{7}$ plaque-forming particles and approximately $10^{8}$ bacteria $/ \mathrm{ml}$., i.e. a ratio of about $1: 10$. This is regarded as 'limit' dilution, the dilution at which each phage particle will in general infect a single bacterium. The phage-bacteria mixture was immediately placed in a waterbath at $37^{\circ}$ for $10 \mathrm{~min}$. to allow adsorption to take place, and thereafter rapidly diluted $10^{-5} \times 1 / 5$ in broth. Volumes of $0.5 \mathrm{ml}$. of this dilution were flooded on to plates of nutrient agar which had been impregnated with $10^{9}$ particles/ml. of the virulent $(\gamma)$ mutant of the phage under investigation. On such a medium only bacteria which had been lysogenized by the temperate phage multiplied and formed colonies: productively infected bacteria disintegrated, and all non-lysogenized (sensitive) bacteria were destroyed. After overnight incubation, the average number of colonies per plate $\times 10^{6}$ gave the number of lysogenizing particles per ml. of the phage-bacteria mixture, and a further calculation in terms of the preliminary dilution gave the count in the original concentrate. The accuracy of this method of estimating lysogenized bacteria has been tested by plating equal quantities of phage-bacteria mixture on $(a)$ nutrient agar and $(b)$ nutrient agar impregnated with virulent phage. Each colony developing on $(a)$ was tested independently for lysogenesis. The totals of the lysogenic colonies on $(a)$ and $(b)$ in a series of experiments with graded phage concentrations are shown in Fig. 1. If anything, the percentage of lysogenization revealed by the impregnated plate technique was lower than in the control, a finding which indicates that multiple infection with $\gamma$ particles does not produce lysogenization. In this and all subsequent experiments, the percentage of bacteria lysogenized-or lysed-was calculated in terms of the count of viable bacteria in the control culture which was included in every experiment. 
The second half of the count-the estimation of the number of particles which give productive infection-was a continuation of the same experiment. Another portion of the phage-bacteria mixture was diluted in broth $10^{-7} \times 1 / 16$, and distributed in quantities of $0.4 \mathrm{ml}$. in 200 small sterile test-tubes. This gave an average of 1 bacterium per 4 tubes, a distribution which made it improbable that more than one bacterium would find its way into any one tube. As, at the phage dilution used, only

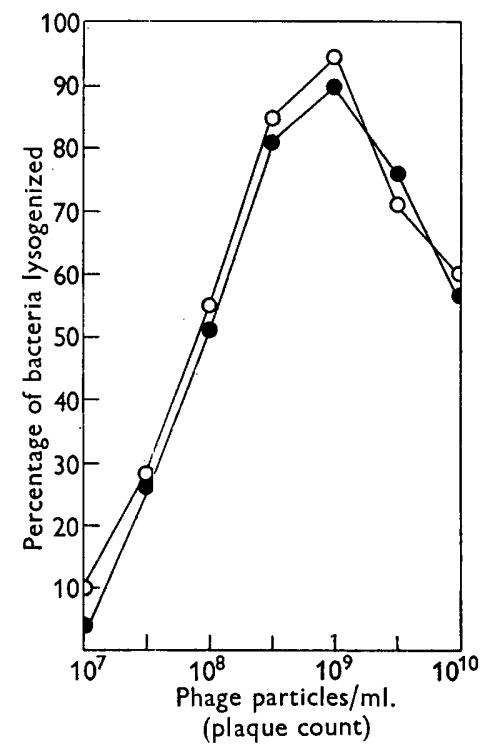

Fig. 1. Comparison of two methods of estimating lysogenization. Q1, at a concentration of $10^{8}$ bacteria/ml., was exposed to graded concentrations of phage $A 1 b$, and incubated at $37^{\circ}$ for $10 \mathrm{~min}$. The preparations were then diluted $10^{-5} \times 1 / 5$ and equal quantities from each plated on (1) nutrient agar and (2) nutrient agar impregnated with $10^{9}$ particles $/ \mathrm{ml}$. of A1b $\gamma$. All colonies which developed on (1) were tested for lysogenesis. Only lysogenic colonies developed on (2). $O$, Percentage of bacteria lysogenized, calculated from (1); $\checkmark$, percentage of bacteria lysogenized, calculated from (2).

about 1 in 10 of these bacteria was phage-infected, the chance of more than one productively infected bacterium being in any one tube can be disregarded. The tubes were then incubated at $37^{\circ}$ for 90 min. Thereafter a loopful from each was placed on a numbered section of a lawn of Q1, and incubated overnight. The presence of multiple plaques on any one section indicated a burst. If a section showed only one plaque, which might be produced by a residual free phage particle, a larger sample was tested. With the above technique and dilutions, the number of tubes showing bursts multiplied by $2 \times 10^{6}$ gave the number of $\beta$ particles $/ \mathrm{ml}$. of phage-bacteria mixture.

\section{Lysogenization and productive infection at limit dilution in the Type $A$ phages}

The results of a series of counts of phages A1 $b$ and A2 $d$ by the methods described are recorded in Tables 4 and 5 . These are two phages used in many of the experiments to be described, as they are representative types having respectively high and low lysogenizing properties. In both cases the sum of the $\alpha$ and $\beta$ particles, 
which will be taken as the true count, was higher than the plaque count, though this difference was more marked in A1b than in A2d. Counts of particles carried out in this way at limit dilution gave relatively constant and repeatable results, both in the same batch and in different batches of any one phage. These relative proportions of $\alpha$ and $\beta$ particles appear therefore to be a stable character of each particular phage when prepared and tested by the methods described.

Table 4. Comparison of counts of particles in temperate phage $A 1 b$ made by enumerating lysogenic bacteria and bursts, and by plaque count

The counts of lysogenic bacteria and bursts were made from a standard phage-bacteria mixture containing $1.1 \times 10^{7}$ particles $/ \mathrm{ml}$. (as estimated by plaque count).

\begin{tabular}{|c|c|c|c|c|}
\hline Expt. & $\begin{array}{c}\text { Lysogenic } \\
\text { bacteria }\end{array}$ & Bursts & $\begin{array}{c}\text { Sum of } \\
\text { lysogenic bacteria } \\
\text { and bursts }\end{array}$ & $\begin{array}{l}\text { Plaque } \\
\text { count }\end{array}$ \\
\hline 1 & $8.25 \times 10^{6}$ & $1.0 \times 10^{7}$ & $1.825 \times 10^{7}$ & - \\
\hline 2 & $9.5 \times 10^{6}$ & $6.0 \times 10^{6}$ & $1.55 \times 10^{7}$ & - \\
\hline $\mathbf{3}$ & $9.0 \times 10^{6}$ & $4.0 \times 10^{6}$ & $1.3 \times 10^{7}$ & - \\
\hline 4 & $9.25 \times 10^{6}$ & $8.0 \times 10^{6}$ & $1 \cdot 725 \times 10^{7}$ & - \\
\hline Average & $9 \cdot 0 \times 10^{6}$ & $7 \cdot 0 \times 10^{6}$ & $1 \cdot 6 \times 10^{7}$ & $1 \cdot 1 \times 10^{7}$ \\
\hline
\end{tabular}

Note. The discrepancy between the plaque count and the bursts is attributable to the fact that newly lysogenized bacteria are unstable, and frequently, after 3 or 4 divisions, produce daughter cells in which productive development occurs. The liberation of free phage in this way produces, in the fully incubated plate, plaques of a size related to their time of origin, early ones being large and late ones small.

Table 5. Comparison of counts of particles in temperate phage A2d made by enumerating lysogenic bacteria and bursts, and by plaque count

The counts of lysogenic bacteria and bursts were made from a phage-bacteria mixture containing $1.0 \times 10^{7}$ particles $/ \mathrm{ml}$. (as estimated by plaque count).

$\begin{array}{ccccc}\text { Expt. } & \begin{array}{c}\text { Lysogenic } \\ \text { bacteria }\end{array} & \text { Bursts } & \begin{array}{c}\text { Sum of } \\ \text { lysogenic bacteria } \\ \text { and bursts }\end{array} & \begin{array}{c}\text { Plaque } \\ \text { count }\end{array} \\ 1 & 1.85 \times 10^{6} & \mathbf{9 . 6} \times 10^{6} & 1.15 \times 10^{7} & - \\ 2 & 1.95 \times 10^{6} & 1.1 \times 10^{7} & 1.2 \times 10^{7} & - \\ 3 & 1.15 \times 10^{6} & 1.34 \times 10^{7} & 1.5 \times 10^{7} & - \\ 4 & 1.3 \times 10^{6} & 1.0 \times 10^{7} & 1.13 \times 10^{7} & - \\ 5 & 1.1 \times 10^{6} & 1.2 \times 10^{7} & 1.31 \times 10^{7} & - \\ \text { Average } & 1.47 \times 10^{6} & 1.12 \times 10^{7} & 1.26 \times 10^{7} & 1.0 \times 10^{7}\end{array}$

Counts of all 11 types of $\mathbf{A}$ phage were carried out by these methods at limit dilution. The average of several counts-at least two-is given in Fig. 2, which shows the relative proportions of $\alpha$ and $\beta$ particles. The wide range of variation is a notable feature.

\section{Observations on multiplicity and lysogenization}

It has been pointed out (Boyd, 1951 $b$ ) and confirmed (Lwoff, Kaplan \& Ritz, 1954) that when a sensitive culture is exposed to temperate phage, the percentage of bacteria which becomes lysogenized increases when the bacteria are infected by more than one phage particle. Such multiplicity of infection and subsequent lysogenization is governed partly by the proximity of the bacteria and phage particles, 
and partly by the availability of phage particles. Table 6 records an experiment showing the extent of lysogenization when a culture of $Q 1$ containing $10^{8}$ organisms/ ml. was exposed to widely spaced concentrations of A $1 b$. The peak of lysogenization was reached when the concentration of phage was $10^{9}$ particles $/ \mathrm{ml}$, a phage:bacteria ratio of $10: 1$.

The phage:bacteria ratio is not in itself the dominant factor. Decreasing the number of bacteria, and so increasing the phage: bacteria ratio does not increase the degree of lysogenization (Table 7).

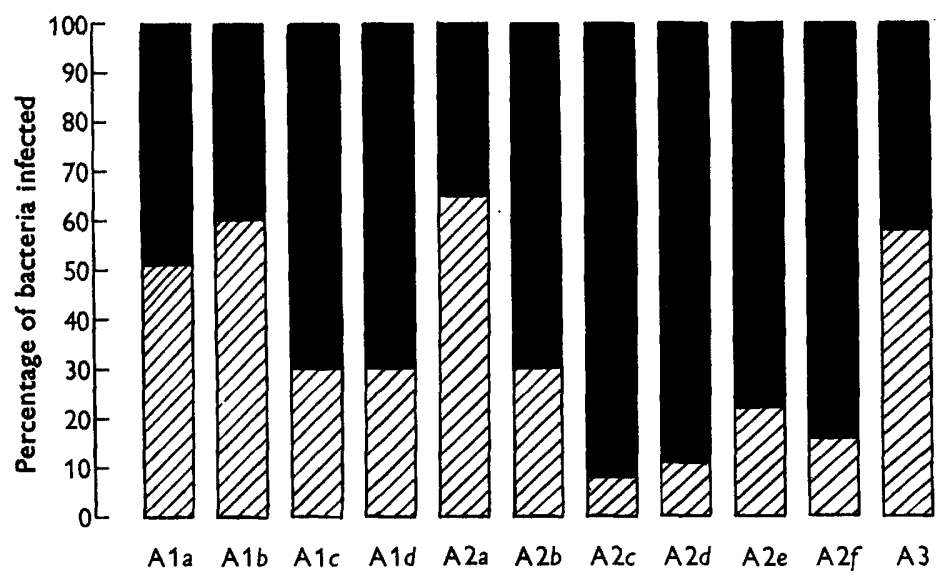

Fig. 2. Relative proportions of $\alpha$ and $\beta$ particles in the $A$ phages. The $\alpha$ (lysogenizing) and $\beta$ (productive infection) particles in each phage were counted, at limit dilution, by the method described. $\square, \alpha$ particles; $\boldsymbol{n}, \beta$ particles.

Table 6. Relationship of phage concentration and lysogenization

(Q1 and $\mathrm{A} 1 b)$

Mixtures of $Q 1$ and $A 1 b$ were prepared by the methods described, and incubated at $37^{\circ}$ for $10 \mathrm{~min}$. to allow adsorption to occur. Thereafter they were appropriately diluted and plated on agar impregnated with $A 1 b \gamma$. The percentage of bacteria which had become lysogenized was calculated from the number of colonies which developed. The figures given are the average of several experiments.

\begin{tabular}{|c|c|c|c|c|c|c|c|}
\hline $\begin{array}{l}\text { Concentration of phage } \\
\text { particles } / \mathrm{ml} \text {. }\end{array}$ & $1.0 \times 10^{7}$ & $3.1 \times 10^{7}$ & $1 \times 10^{8}$ & $3.1 \times 10^{8}$ & $1.0 \times 10^{9}$ & $3.1 \times 10^{9}$ & $1.0 \times 10^{10}$ \\
\hline $\begin{array}{l}\text { Phage : bacteria ratio } \\
\text { (approximate) }\end{array}$ & $0 \cdot 1: 1$ & $0.31: 1$ & $1: 1$ & $3 \cdot 1: 1$ & $10: 1$ & $31: 1$ & $100: 1$ \\
\hline $\begin{array}{l}\text { Percentage of bacteria } \\
\text { lysogenized }\end{array}$ & $5 \cdot 0$ & $18 \cdot 0$ & $38 \cdot 0$ & $77 \cdot 0$ & $87 \cdot 0$ & $77 \cdot 0$ & 65.5 \\
\hline
\end{tabular}

On the other hand, when the bacterial concentration is lowered, lower phage concentrations, within limits, give an equally high degree of lysogenization, as the bacteria have the opportunity to come in contact with and adsorb a greater number of particles (Table 8).

These results emphasize the need for a standard technique, if consistent and comparable results are to be obtained. It is for this reason that bacterial suspensions containing approximately $10^{8}$ viable organisms $/ \mathrm{ml}$. have been used in all experiments. 


\section{Lysogenesis and productive development at different phage concentrations}

\section{Phage $A 1 b$}

Experiments were carried out in which Q1 was exposed to different concentrations of $A \mathbf{1} b$. Thereafter estimations were made of the percentage of bacteria lysogenized, the percentage of bacteria which underwent productive development, the percentage which escaped phage infection, and the percentage 'unaccounted for' (in low phage concentrations a small and variable number attributable to unavoidable experimental error). Figure 3 gives in graphic form the results of a series of experiments with $\mathrm{A} 1 \mathrm{~b}$, using widely spaced phage concentrations, and Fig. 4, the results of a more closely spaced series.

Table 7. Lysogenization with constant phage concentration and decreasing bacterial concentration

\begin{tabular}{|c|c|c|c|c|c|c|}
\hline Phage particles/ml. & $7.5 \times 10^{8} 7.5 \times 10^{8}$ & $7 \cdot 5 \times 10^{8}$ & $7 \cdot 5 \times 10^{8}$ & $7 \cdot 5 \times 10^{8}$ & $7 \cdot 5 \times 10^{8}$ & $7 \cdot 5 \times 10^{8}$ \\
\hline Viable bacteria/ml. & $9.3 \times 10^{7} 4.65 \times 10^{7}$ & $2 \cdot 325 \times 10^{7}$ & $1 \cdot 162 \times 10^{7}$ & $5.81 \times 10^{6}$ & $2.9 \times 10^{6}$ & $1.45 \times 10^{6}$ \\
\hline Phage :bacteria ratio & $7 \cdot 5: 1$ & $30: 1$ & $60: 1$ & $120: 1$ & $240: 1$ & $480: 1$ \\
\hline Lysogenized bacteria/ & $.7 \cdot 5 \times 10^{7} 3.93 \times 10^{7}$ & $2 \cdot 05 \times 10^{7}$ & $9 \cdot 46 \times 10^{6}$ & $4.42 \times 10^{8}$ & $2.4 \times 10^{6}$ & $1.1 \times 10^{6}$ \\
\hline$\%$ lysogenized & 80 & 88 & 81 & 76 & 82 & 77 \\
\hline
\end{tabular}

Table 8. Lysogenization when bacterial concentration is low

Against lower bacterial concentrations, lower phage concentrations produce a higher percentage of lysogenization.

\begin{tabular}{|c|c|c|c|c|}
\hline & \multicolumn{4}{|c|}{ Phage particles/ml. (A $1 b$ ) } \\
\hline & $10^{7}$ & $10^{8}$ & $10^{9}$ & $10^{10}$ \\
\hline Bacteria/ml. & \multicolumn{4}{|c|}{$\%$ bacteria lysogenized } \\
\hline $10^{8}$ & $8 \cdot 5$ & 51 & 85 & 55 \\
\hline $10^{6}$ & $40 \cdot 0$ & 84 & $83 \cdot 5$ & $58 \cdot 5$ \\
\hline
\end{tabular}

The first column in Fig. 3, in which the phage: bacteria ratio is $1: 10$, represents limit dilution, and shows the respective proportions of $\alpha$ and $\beta$ particles in this particular sample of phage. Lysogenization increased at the expense of productive development up to a phage concentration of $4 \times 10^{8}$, and maintained a high level in subsequent concentrations up to $10^{9}$. Beyond this there was a progressive increase both in the percentage of bacteria which ceased to be viable for reasons other than productive development of phage, and, unexpectedly, in the percentage of bacteria in which phage underwent productive development. These increases were balanced by a decrease in the percentage of lysogenized bacteria and by the absence of unaffected bacteria.

Except at limit dilution, the phage:bacteria ratio does not give any exact indication of the number of particles adsorbed by the infected bacteria. Although in ratios of $1: 1$ and under, over $95 \%$ of the added phage was adsorbed before the calculation was obscured by phage production from lysing bacteria (Fig. 5) the number of bacteria infected was less than the number of phage particles available (Figs. 3, 4), 
and it can be assumed that the excess phage was shared by the infected bacteria in accordance with the Poisson distribution. Thus in ratios as low as 0.31:1 some of the bacteria adsorbed more than one particle.

\section{Phage A2d}

As A2d, when examined at limit dilution, has been found to contain a lower percentage of $\alpha$ particles and a higher percentage of $\beta$ particles than Alb (Fig. 2), the action of this phage on $Q 1$ at different concentrations was investigated in the

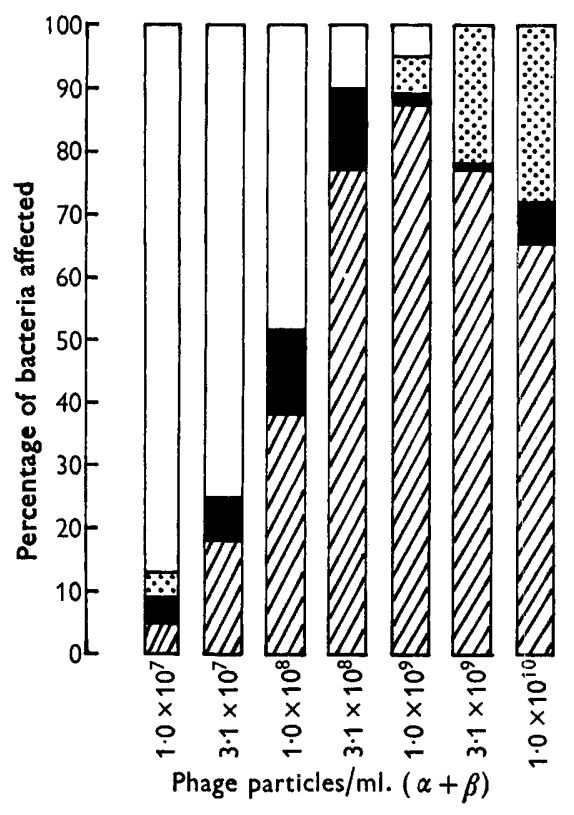

Fig. 3

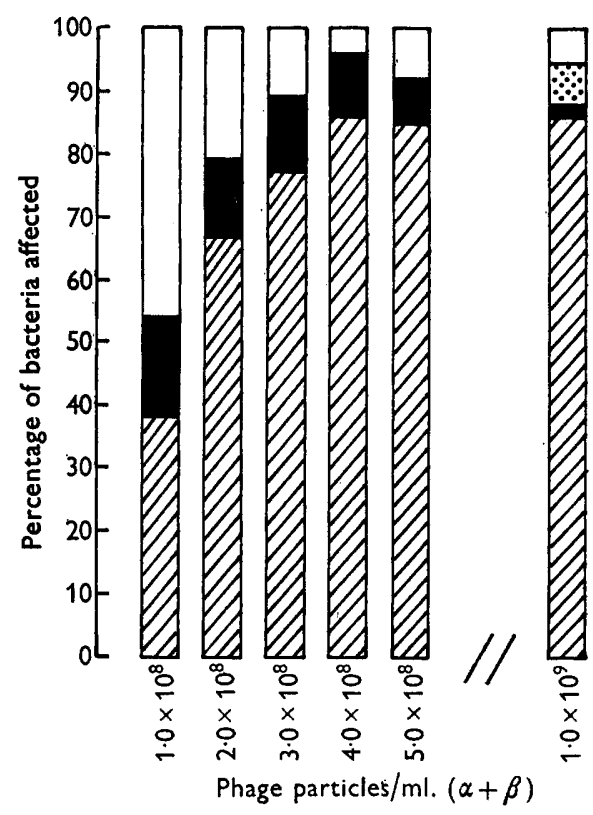

Fig. 4

Fig. 3. Action of widely spaced rising concentrations of $A 1 b$ on $Q 1$. Q1 (10 $10^{8}$ bacteria/ml.) was exposed for $10 \mathrm{~min}$. at $37^{\circ}$ to the phage concentrations indicated. Thereafter the percentage of lysogenized bacteria and the percentage of bursts was determined by the methods described. The percentages of 'bacteria uninfected' and bacteria 'lost' were calculated from the viable count of a control bacterial suspension to which no phage was added. In this figure, the phage concentrations are based on true counts, i.e. the sum of $\alpha$ and $\beta$ particles calculated at limit dilution. Each column is the average of 2 or more experiments. $\square$, Lysogenics; $\square$, bursts; 圈, bacteria lost; $\square$, bacteria uninfected.

Fig. 4. Minimum concentration of $A 1 b$ needed for maximum lysogenization of Q1. A similar experiment to that recorded in Fig. 3, but with closely spaced phage concentrations. Same key as for Fig. 3.

same way as was A1b. The results are shown graphically in Fig. 6, and can be seen to conform to the same general pattern. Maximum lysogenization, which however was at a lower level than with A1 $b$, occurred at a similar phage concentration and increased in the same way at the expense of productive infection. The percentage of bursts was higher at all concentrations than in the case of A1b. 
Relationship of the number of $\alpha$ particles to the number of bacteria lysogenized when exposed to different concentrations of temperate phage

Suspensions of all 11 type A phages were prepared at limit dilution and in accurately measured ascending concentrations thereof. Standard suspensions of Q1 were exposed to these phages, and the number of bacteria lysogenized in a given unit (actually $0.5 \mathrm{ml}$. of a $10^{-5} \times 1 / 5$ dilution of the original mixture) were estimated in the usual way. The number of bacteria lysogenized at limit dilution revealed the

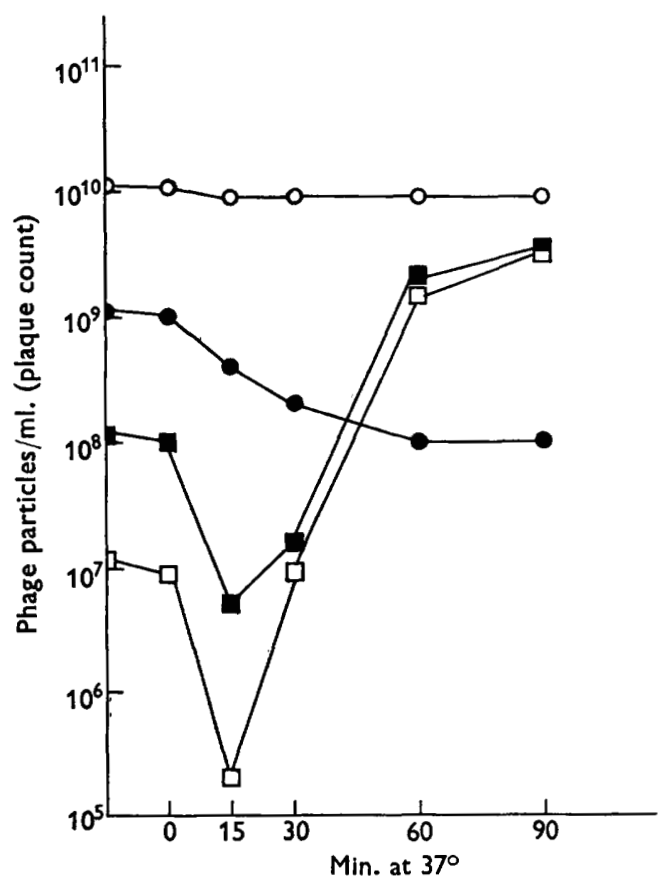

Fig. 5. Adsorption of $A 1 b$ on Q1. A $1 b$ was added to suspensions of $Q 1$ (10 $10^{8}$ bacteria/ml.) to give the concentrations indicated. Samples were removed at intervals and immediately heated to $70^{\circ}$ for $30 \mathrm{~min}$. to kill the bacteria. The curves are plaque counts of free phage particles. Phage concentration: $0,10^{10} / \mathrm{ml}$; $O, 10^{9} / \mathrm{ml}$; $110^{8} / \mathrm{ml}$; $\square 10^{7} / \mathrm{ml}$.

number of $\alpha$ particles in this particular unit. From this the number of 'available' particles in units of the higher concentrations was calculated. In Fig. 7 the number of bacteria actually lysogenized is shown in relation to the number of $\alpha$ particles available. It will be seen that in some cases the $\alpha$ particles were in excess of the bacteria lysogenized, while in other cases the reverse held good. These results will be analysed in the Discussion.

The well-marked variations in lysogenization resulting from exposure to the different phages were not due to a smaller number of bacteria becoming phageinfected because of defective adsorption. Experiments on a more limited range of concentrations, in which both lysogenization and productive development were estimated (Table 9), showed that, while variations occurred in the total number of bacteria infected, these were not related to the degree of lysogenization. Thus A2b 
produced a relatively low rate of lysogenization associated with a high percentage of infection, while A2c had an opposite reaction in the top ratio, namely a higher degree of lysogenization with a much lower percentage of infection. The exceptionally low percentage of infected bacteria in the 10:1 ratio of A2c was associated with a high percentage of 'bacteria lost', and may be attributable to unusually active 'lysis-from-without'.

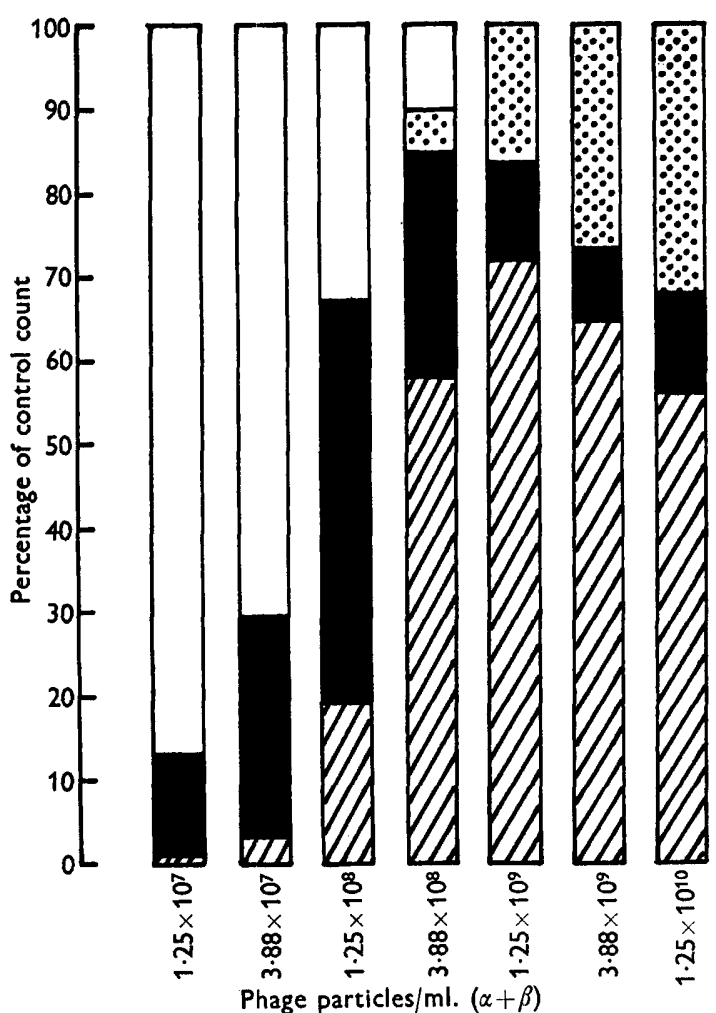

Fig. 6. Action of widely spaced concentrations of A2d on Q1. A similar experiment to that recorded in Fig. 8, but with A2d. $囚$, Lysogenics; $\square$, bursts; 圈, bacteria lost; $\square$, bacteria uninfected.

\section{Lethal action of high concentrations of temperate phage}

Andrewes \& Elford (1932) drew attention to the fact that an excess of virulent phage brought about destruction of a number of bacteria without any increase of free phage-a phenomenon which they called 'lysis-from-without'. This phenomenon has frequently been described in relation to virulent phage. Lieb (1953) mentions results which suggest similar action in the case of temperate phage $\mathrm{R}$, on Escherichia coli $\mathrm{K} 12 \mathrm{~S}$. It can be seen from Fig. 3 that, in one of the lower phage concentrations, a small percentage of bacteria is 'lost'. This is a not uncommon experimental error attributable to minor variations in the viable counts of the control and the test suspensions. In higher concentrations-from $10^{9}$ onwards-there is a progressive increase in the number of 'missing' organisms (Figs. 3,6). Although there is no 
Phage: bacteria

(Approximate ratio)
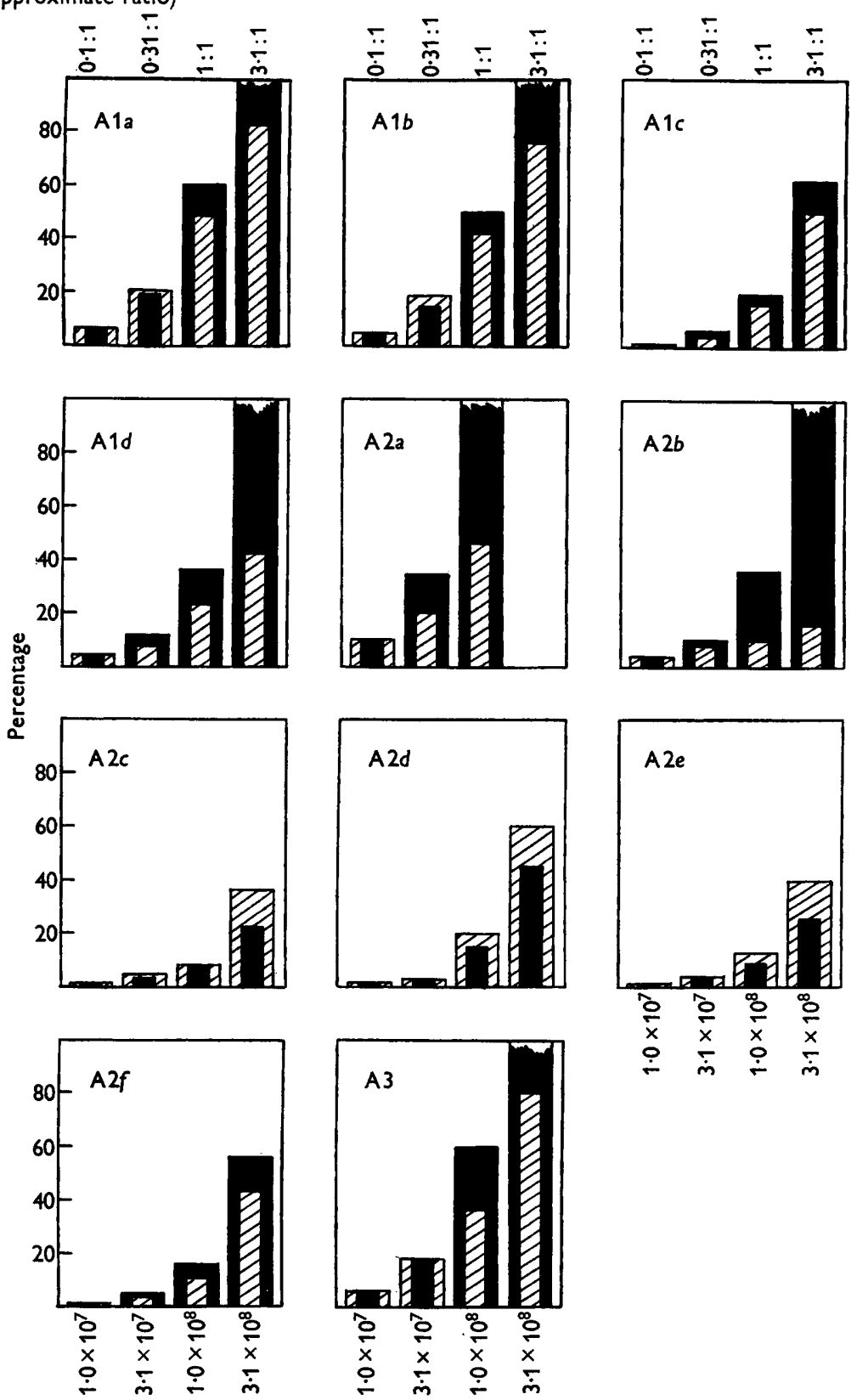

Fig. 7. Relationship of $\alpha$ particles to lysogenesis. Suspensions of Q1 (10 $1 \mathrm{bacteria}^{8} \mathrm{ml}$.) were exposed to graded concentrations of the phages and the percentage of bacteria lysogenized estimated by the usual technique. The percentage of $\alpha$ particles 'available' in each phage concentration was calculated from the figure obtained at limit dilution. For convenience in comparing results the lower figure in each column is shown within the higher. $\square, \alpha$ particles in this phage concentration; $\square$, bacteria lysogenized. 
definite proof that these bacteria were destroyed by lysis-from-without, the picture resembles so closely that found in similar experiments with virulent phage that it leaves little doubt that the bacteria have been killed in this way. A control experiment using corresponding concentrations of the original phage lysate which had been filtered through a gradacol membrane to remove phage particles gave negative results.

Table 9. Percentage of bacteria infected at different ratios

\begin{tabular}{|c|c|c|c|c|c|c|c|}
\hline \multirow{2}{*}{$\begin{array}{c}\text { Phage : bacteria } \\
\text { ratio }\end{array}$} & \multirow[b]{2}{*}{$\%$} & \multicolumn{2}{|c|}{$\begin{array}{l}\text { Phages containing } \\
\text { high proportion } \\
\text { of } \alpha \text { particles }\end{array}$} & \multicolumn{2}{|c|}{$\begin{array}{l}\text { Phages containing } \\
\text { medium proportion } \\
\text { of } \propto \text { particles }\end{array}$} & \multicolumn{2}{|c|}{$\begin{array}{l}\text { Phages containing } \\
\text { low proportion } \\
\text { of } \alpha \text { particles }\end{array}$} \\
\hline & & $A 1 b$ & A2 $a$ & Ald & $A 2 b$ & A2c & A2d \\
\hline $0 \cdot 1: 1$ & $\begin{array}{l}\text { Lysogenics } \\
\text { Bursts } \\
\text { Total infected }\end{array}$ & $\begin{array}{r}7 \cdot 9 \\
5 \cdot 5 \\
13 \cdot 4\end{array}$ & $\begin{array}{r}8 \cdot 7 \\
4 \cdot 6 \\
13 \cdot 3\end{array}$ & $\begin{array}{r}3 \cdot 6 \\
8 \cdot 8 \\
12 \cdot 4\end{array}$ & $\begin{array}{r}3 \cdot 6 \\
8 \cdot 5 \\
12 \cdot 1\end{array}$ & $\begin{array}{r}0 \cdot 8 \\
9 \cdot 3 \\
10 \cdot 1\end{array}$ & $\begin{array}{l}1 \cdot 25 \\
11 \\
12 \cdot 25\end{array}$ \\
\hline $1: 1$ & $\begin{array}{l}\text { Lysogenics } \\
\text { Bursts } \\
\text { Total infected }\end{array}$ & $\begin{array}{l}49 \cdot 25 \\
14 \cdot 75 \\
64 \cdot 0\end{array}$ & $\begin{array}{l}41 \cdot 25 \\
30 \\
71 \cdot 25\end{array}$ & $\begin{array}{l}\mathbf{2 2 \cdot 3} \\
\mathbf{3 6} \cdot 0 \\
\mathbf{5 8 \cdot 3}\end{array}$ & $\begin{array}{l}15 \cdot 7 \\
58 \cdot 0 \\
\mathbf{7 3} \cdot 7\end{array}$ & $\begin{array}{l}10 \\
48 \\
58\end{array}$ & $\begin{array}{l}19 \\
48 \\
67\end{array}$ \\
\hline $10: 1$ & $\begin{array}{l}\text { Lysogenics } \\
\text { Bursts } \\
\text { Total infected }\end{array}$ & $\begin{array}{c}89 \\
1.5 \\
90 \cdot 5\end{array}$ & $\begin{array}{l}80 \cdot 5 \\
17 \cdot 7 \\
98 \cdot 2\end{array}$ & $\begin{array}{l}70 \cdot 0 \\
20 \cdot 0 \\
90 \cdot 0\end{array}$ & $\begin{array}{l}41 \cdot 5 \\
51 \cdot 0 \\
92 \cdot 5\end{array}$ & $\begin{array}{r}61 \cdot 0 \\
7 \cdot 3 \\
68 \cdot 3\end{array}$ & $\begin{array}{l}72 \\
12 \\
84\end{array}$ \\
\hline
\end{tabular}

Table 10. Lysis-from-without produced by $A 1 b \gamma$

Q1 was exposed to $A 1 b \gamma$ in the concentrations recorded, incubated at $37^{\circ}$ for $10 \mathrm{~min}$., diluted $10^{-7} \times 1 / 16$, and distributed in $0.4 \mathrm{ml}$. quantities in 200 tubes. At the same time appropriate quantities were plated to estimate viable survivors. After the tubes had been incubated at $37^{\circ}$ for $2 \mathrm{hr}$., a loopful from each was spotted on a lawn of Q1 to ascertain the number of tubes in which bursts had occurred.

$\begin{array}{cccc}\begin{array}{c}\text { Phage } \\ \text { particles/ml. }\end{array} & \overbrace{}^{\text {Surviving }} & \begin{array}{c}\text { 'Missing' } \\ \text { bacteria }\end{array} \\ 10^{7} & \text { Bursts } & \text { Percentage of } & \\ 10^{8} & 10 \cdot 6 & 85 \cdot 4 & 4 \cdot 0 \\ 10^{9} & 62 \cdot 5 & 23 \cdot 6 & 13 \cdot 9 \\ 10^{10} & 82 \cdot 0 & 1 \cdot 3 & 16 \cdot 7 \\ & 63 \cdot 0 & 1 \cdot 0 & 36\end{array}$

Confirmatory evidence of the lysis-from-without phenomenon was provided by experiments in which $\mathrm{Q} 1$ was exposed, not to temperate phage $\mathbf{A} 1 b$, but to its virulent mutant, $\mathrm{A} 1 b \gamma$, which does not produce lysogenesis. The effect of different phage concentrations on the percentage of bacteria in which the phage underwent productive development was investigated by the usual technique. The results of one series of experiments are given in Table 10. The percentage of bacteria which supported productive development was approximately the same as the percentage of bacteria which were lysogenized by temperate phage, and at high phage concentrations there was a similar decrease in the number of infected bacteria, presumably due to lysis-from-without. 


\section{Productive infection in high concentrations}

An unexpected and constant finding in experiments with $\mathrm{A} 1 b$, which was present but less obvious in the case of A2d, was that productive infection reached its minimum at a phage concentration of around $10^{9}$ particles $/ \mathrm{ml}$. and tended to increase in the higher concentrations (Figs. 3, 6). It would therefore appear, in a heavy multiple infection, either that lysogenesis is not established, and productive development supervenes, or that the immunity which lysogenesis affords breaks down. This problem was explored by exposing an established strain of Q1 (A1 $b)$ to the action of different concentrations of A1 b, and examining for bursts in the usual way. With a phage concentration of $10^{9}$ particles/ml., no productive infection occurred, while at $10^{9} \times 5,6 \%$, and at $10^{10}, 8 \%$ of the bacteria showed productive infection.

In these experiments there was no evidence of lysis-from-without, although $\mathbf{A} 1 b$ is as freely adsorbed to $\mathrm{Q} 1(\mathrm{Al} b)$ as to $\mathrm{Q} 1$. Counts of viable bacteria made before and after exposure to the phage showed no significant variation other than the decrease attributable to the bursts.

Q1 $(\mathrm{A} 2 d)$ is immune to $\mathrm{A} 1 b$ in concentrations of $10^{9}$ particles $/ \mathrm{ml}$. When Q1 (A2d) was exposed to $10^{10}$ particles $\mathrm{A} 1 \mathrm{~b} / \mathrm{ml}$. some $6 \%$ of the cells burst, liberating particles of A1 $b$ and A2d in approximately equal numbers. Thus it would seem that, although Q1 (A2d) is immune to low concentrations of A1b, a high multiple infection with A1b induces Q1 (A2d). The significance of these results will be discussed later.

\section{Influence of temperature on lysogenization and productive development}

Bertani \& Nice (1954) found that incubation of infected bacteria at a temperature of $20^{\circ}$ for $2 \mathrm{hr}$. blocked the productive development of phage $\mathrm{Pl}$, and also of its virulent mutant, whereas the proportion of infected bacteria which became lysogenized was much higher at a temperature of $20^{\circ}$ than at $37^{\circ}$. Temperate phage $\mathbf{P 2}$ did not react in this way. This observation was investigated, burst experiments being carried out with $A 1 b$ at a phage:bacteria ratio of $0.75: 1$. One portion was incubated at $37^{\circ}$, the other at $20^{\circ}$. In one the percentage of bursts was $17 \cdot 2$ and in the other 18. Thus there was no significant difference and no suppression of productive development as found in the case of P1. Similar results were obtained in further experiments using different phage concentrations, in which both lysogenesis and productive development were estimated. Like $\mathbf{P 2}, \mathbf{A l} b$ is therefore unaffected in this way by incubation at low temperature.

Lieb (1953) reports that, in the case of Escherichia coli and phage $\lambda$, the temperature to which the bacteria are exposed during the first 1 to $1 \frac{1}{2} \mathrm{hr}$. after infection has a predominant influence on the proportion of lysogenics in clones, i.e. in the progeny of what are believed to be single cells. This is a different type of phenomenon from that described by Bertani, but it was considered of interest to find out if exposure to a high temperature affected the lytic or productive response of Q1 infected with A1 $b$. The standard technique was used and the results are given in Table 11. The higher temperature reduced the number of bacteria which showed the effects of phage infection, presumably due to restricted bacterial growth, but the relative proportions of bacteria lysogenized and bacteria productively infected did not vary significantly from the control. 


\section{Influence of organic acids on lysogenization}

Lwoff et al. (1954) using Al $a$ and Salmonella typhimurium 1404 as indicator, report that specified concentrations of the potassium salts of certain organic acids (citric, malic, oxaloacetic, malonic, pyruvic, lactic, and pyrophosphoric) increase productive infection from 3 to 5 times, presumably at the expense of lysogenic infection. Early experiments carried out with the same phage and indicator some years ago failed to confirm this claim, the only significant action observed, with the methods and media then in use, being some interference with adsorption and consequent slight reduction in the number of bacteria which became phage infected.

\section{Table 11. Influence of high temperature on lysogenization}

The $\mathbf{A} 1 b: \mathbf{Q} 1$ ratio in all cases was $0 \cdot 75: 1$. Lysogenization and productive infection were ascertained by the standard technique.

$\begin{array}{lcc}\mathbf{3 7}^{\circ} & 42^{\circ} \\ \text { \% lysogenized } & \begin{array}{c}\text { Temperature of } \\ \text { incubation }\end{array} \\ \text { \% productively infected } & \mathbf{1 3 \cdot 5} & \mathbf{9 \cdot 3}\end{array}$

* The figures under $42^{\circ}$ are the average of 2 experiments.

Table 12. Influence of citrate and malonate on lysogenization

Lwoff's synthetic medium was used throughout. The concentration of phage $A 1 b$ in all experiments was $7.5 \times 10^{7} / \mathrm{ml}$. Lysogenesis and productive infection were ascertained by the standard technique.

Synthetic medium control Synthetic medium + potassium citrate $10^{-2} \mathrm{M}$

Synthetic medium + potassium malonate $2 \times 10^{-2} \mathrm{M}$

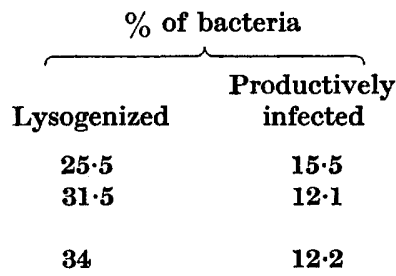

$12 \cdot 2$

The action of potassium citrate and potassium malonate has been re-investigated with $A 1 b$ and Q1, but using Lwoff's synthetic medium instead of Lemco broth. The results confirmed those given by the earlier experiments. There was no gross variation in productive development, and only a slight increase in lysogenization (Table 12). Lwoff's synthetic medium was used throughout and in the control the degree of lysogenization was less than is found in Lemco broth. The concentration of $\mathrm{A} 1 \mathrm{~b}$ in all experiments was $7.5 \times 10^{7} / \mathrm{ml}$. In further experiments with A $1 a$ and 1404 at a 5:1 ratio, in which only lysogenization was estimated, there was a slight reduction in the percentage of organisms lysogenized $(41.5 \%$ control, $36.5 \%$ with potassium citrate $\mathrm{M} / 10^{-2}, 33.25 \%$ with potassium malonate $\mathrm{M} / 2 \times 10^{-2}$ ). In view of the results given by the early experiments, this can be attributed to some interference with adsorption. In the absence of a marked decrease in lysogenesis, no significant increase in productive infection can have occurred. 


\section{Influence of anaerobiosis on lysogenization}

It has been stated that anaerobiosis decreases the proportion of lysogenic responses (Lwoff, 1953). No such phenomenon was observed in experiments with A1 $b$ and A2 $d$ (Table 13). Two sets of plates were inoculated with aliquots of phageinfected bacterial suspensions prepared by the standard technique, and one set was incubated aerobically, the other anaerobically. The colonies which developed on the plates incubated anaerobically were considerably smaller than those which grew under aerobic conditions, but numerically there was no difference. Two further experiments similar to the above were carried out, in which anaerobiosis was maintained at all stages of the experiment, and not merely during incubation of the plates. Once again the only difference was in the size of the 'anaerobic' colonies, which were much smaller than those in the control.

\section{Table 13. Influence of anaerobiosis on lysogenization}

The assessment of lysogenization was made by the standard technique. The controls, which are not shown in the table, were normal.

\begin{tabular}{|c|c|}
\hline $\begin{array}{l}\text { Incubated } \\
\text { aerobically }\end{array}$ & $\begin{array}{c}\text { Incubated } \\
\text { anaerobically }\end{array}$ \\
\hline 29 & $28 \cdot 3$ \\
\hline 12 & 12 \\
\hline
\end{tabular}

\section{Influence of chloramphenicol on lysogenization}

In contrast to these negative results, chloramphenicol had a well-marked influence on lysogenization. This is a reaction of considerable complexity which it is hoped to make the subject of a separate paper.

\section{DISCUSSION}

An essential prerequisite for the study of the processes of lysogenization is a reliable technique for estimating the percentage of bacteria lysogenized and the percentage productively infected when a culture of sensitive bacteria is exposed to the action of temperate phage. The methods which have been elaborated for this purpose are given in detail in the first part of this communication, and do not require further discussion. They are considered to be reliable and accurate, and have been found to give repeatable results. The method of estimating the numbers of productively infected bacteria by counting plaques ('lytic centres') has proved unreliable with the systems we are investigating. We have found that newly lysogenized Q1 is relatively unstable, and may, after a few divisions, throw off a daughter cell in which the phage undergoes productive development. If this occurs before the bacteria in the sensitive lawn have multiplied to any appreciable extent, the free phage thus liberated forms a plaque which is smaller than but otherwise indistinguishable from the plaque produced by an organism productively infected $a b$ initio. We have not used as a routine the method described by Levine (1957) turning on the use of $\mathrm{gal}^{+}$and gal- strains of Salmonella typhimurium, as the gal $^{-}$: indicator strains available at the time this work was done were found to contain $B$ 
phages (Boyd, 1950) and were insensitive to several of the type A phages of the series.

When Q1 was exposed to one of these temperate phages at a concentration sufficiently low to ensure that only single infection occurred it was found that some of the infected bacteria were lysogenized and others were productively infected. The proportions of lysogenized and productively infected bacteria were, within the limits of experimental error, constant in repeated tests of the same batch of phage and in other batches of the same phage made by the same technique but at a different time. Thus it can be concluded (a) that a temperate phage consists of a mixture of particles, some ( $\alpha$ particles) endowed with the property of producing lysogenesis, and others ( $\beta$ particles) incapable, as single infections, of doing so and going on instead to productive development, and $(b)$ that the two types of particle, under standard conditions, are present in relatively constant proportions in each temperate phage.

Eleven of the 12 type A temperate phages (Fig. 2) were investigated in this way (type A4 had to be excluded as no virulent mutant of this phage has been isolated). The proportions of $\alpha$ and $\beta$ particles varied greatly from phage to phage, though each type behaved consistently. In some the $\alpha$ particles were equal in number to or even more numerous than $\beta$ particles, in others they constituted as little as $8 \%$ of the total. These accurate estimates of the two varieties of particle in any one temperate phage, and the demonstration of their presence in varying proportions in the 11 members of the series, provide a useful means of studying certain of the problems of lysogenization.

It has been suggested (Parry \& Edwards, 1953) that the decision towards lysogenesis or productive development of the phage turns on the interplay of two factors, namely varying degrees of virulence on the part of the phage particles and varying degrees of resistance to lysis on the part of the bacteria. However, in view of the wide variation in the pattern of lysogenesis and lysis shown by the 11 phages when tested against the same bacterial suspension, it is obvious that under these conditions bacterial resistance plays a secondary role in determining the outcome of phage infection. Clearly the dominating factor is in the phage particle, and is a constant feature of each particular type. This point is well demonstrated by the results given by $A 1 b$ and $A 2 d$ (Figs. 3, 6), in which the differences recorded have been confirmed in experiments repeated at long intervals of time and with different batches of reagents.

In previous papers (Boyd, 1951 $b, 1953$ ), the existence of $\alpha$ and $\beta$ particles was deduced from less convincing experimental evidence, and it was suggested that the explanation of the multiplicity phenomenon might lie in a dominance of $\alpha$ particles over $\beta$ particles. When bacteria were exposed to rising concentrations of phage, increasing numbers would be infected with several particles, some with $\beta$ particles only, some with $\alpha$ and $\beta$ particles. In the latter case the pattern of development, i.e. lysogenesis, would be imposed by the dominant $\alpha$ particle, thus producing a higher degree of lysogenization. This idea has been independently explored by Prell \& Prell (1959). Working with phage P22, which is derived from the same lysogenic bacterium as $A 1 b$ and gives similar reactions, Prell \& Prell found that with low phage: bacteria ratios $(0.3: 1)$ the probability per phage is 0.57 for lysogenization and 0.43 for lysis. This is in good agreement with the finding recorded in Fig. 3. 
Prell \& Prell develop the speculative theory outlined above, and conclude " in multicomplexes the immunity induced by one of the superinfecting phages is superimposed upon the one-hit lytic infection causing the percentage of lysogenization increasing with multiplicity".

Bertani (1960) suggests that calculations of the numbers of bacteria lysogenized by single hits may be complicated by the presence of 'doublets' in the culturedoublets being 'physiologically independent, but incompletely separated, sister bacteria'. He points out that, in a stationary culture, if one half of a doublet is hit by a particle which multiplies productively, the second half will be heavily infected when the first half bursts, and so will run a good chance of being lysogenized by this multiplicity. He points out rightly that this is more likely to increase the proportion of bacteria lysogenized when the phage:bacteria ratio is low. In our experiments the bacteria were actively motile throughout. In the case of $A 1 b$ the proportion of lysogenics and lytics is such that any part played by doublets in increasing lysogenization would be difficult to assess. But from the results given by A2c and A2d, where at limit dilution approximately $10 \%$ or less of the particles give lysogenesis, while $90 \%$ or more give lysis, it can be seen that, with the technique used, the occurrence of late lysogenesis resulting from the lytic infection of one half of a doublet must be relatively rare. As the bacterial suspensions in all these experiments were prepared by standard methods, and therefore contained the same proportion of doublets, it would appear that our results have not been significantly affected by this possibility.

The results recorded graphically in Figs. 3, 4 and 6 show that with rising phage concentrations and hence rising phage:bacteria ratios, resulting in multiple infection of bacteria by phage particles, the maximum degree of lysogenization is reached in phage concentrations between $4 \times 10^{8}$ and $10^{9}$ particles $/ \mathrm{ml}$., at which concentrations two-thirds or more of the phage is adsorbed in $15 \mathrm{~min}$. (Fig. 5). (In the case of $\mathbf{A} 1 b$, calculating from the protocols from which Fig. 5 was constructed, at a concentration of $10^{7}$ (ratio $0 \cdot 1: 1$ ) over $98 \%$ of the phage was adsorbed; at $10^{8}$ (ratio $1: 1$ ) $95 \%$ and at $10^{9}$ (ratio $10: 1$ ) $67.5 \%$. Similar experiments with other phages gave results of the same order.)

At limit dilution (for convenience, a plaque count:bacteria ratio of $1: 10$ ) the relative proportions of $\alpha$ and $\beta$ particles per unit of phage of known concentration are revealed (Fig. 7, Table 9). These figures enable the actual number of $\alpha$ and $\beta$ particles in the accurately measured higher phage concentrations to be calculated. In these higher concentrations the total number of infected bacteria (i.e. both lysogenized and lysed) is less than the total number of phage particles which have been adsorbed. It follows therefore that some infected bacteria have taken up more than one phage particle: the expected distribution can be calculated from the Poisson formula. The total number of bacteria infected by different members of the series and at different concentrations shows some variation (Table 9), but this variation bears no obvious relationship to the proportions of bacteria lysogenized or lysed.

These principles have been employed in constructing the graphs in Fig. 7. The starting point in each case is the first column, which shows the number of bacteria lysogenized by, and hence the number of $\alpha$ particles in, a unit of the phage at limit dilution. The figures recorded in the subsequent columns show the results given by 
identical units of accurately measured rising concentrations of the same phage. The hatched columns show the bacteria lysogenized, while the solid columns show the number of $\alpha$ particles in the unit, calculated from the figure given at limit dilution. To make the results obvious at a glance the lower column of the two is enclosed in the higher.

Three different types of response are revealed in Fig. 7 .

(1) The number of lysogenized bacteria exceeds the number of available $\alpha$ particles. This reaction is seen in the second column (phage concentration $3.1 \times 10^{7}$ ) of A1 $a$ and A1 $b$, and throughout in A2c, A2d, and A2e.

(2) The number of lysogenized bacteria falls significantly below the number of available $\alpha$ particles. This is well marked in the case of A2b, less so in A1d and A2a.

(3) The number of lysogenized bacteria, though lower than the number of $\alpha$ particles, represents approximately the number of bacteria which, in terms of the Poisson distribution, would have been hit by one or more $\alpha$ particles. This is seen in certain concentrations of A1 $a, \mathrm{~A} 1 b, \mathrm{~A} 1 c, \mathrm{~A} 2 f$ and A3.

It must be reiterated that as the same bacterium (Q1) was used throughout these experiments, and as the different phages were adapted to and propagated on this organism, such variations as occur are attributable only to the phage, and thus as far as bacterial resistance is concerned, the different experiments act as controls, one for the other.

The results given by the phages listed under (1) disprove the speculative hypothesis (Boyd, 1951b) that lysogenesis results only when an $\alpha$ particle infects a bacterium, either as a single infection or in association with $\beta$ particles. In the higher concentrations of A2c, A2d, and A2e, the number of bacteria which were lysogenized exceeded the number of $\alpha$ particles in the unit of phage to which they were exposed. On the other hand, in these higher phage concentrations a number of bacteria were infected by two or more particles, which in most cases were $\beta$ particles. It can be assumed that single infections with a $\beta$ particle will produce the same result (a burst) in high as in low phage concentrations, and that the only significant difference between infected bacteria in the high phage concentrations and infected bacteria in the limit phage concentrations was that some of the former were infected by more than one particle. It therefore would appear that in these systems multiple infection, irrespective of whether the particles are $\alpha$ or $\beta$, can bring about lysogenesis, and that when two or more $\beta$ particles enter one bacterium, they act together in some way to produce the conditions essential for lysogenization. A possible but speculative explanation is that $\alpha$ particles possess a component which determines conditions leading to lysogenization: that in individual $\beta$ particles this component is incomplete, but that when the infective material of two or more $\beta$ particles enters a bacterium, the effect is additive, and the necessary conditions for lysogenization are produced.

This finding has something in common with observations made by Kaiser (1957) and Levine (1957). Kaiser studied independently occurring clear plaque-forming mutants of phage, among which he recognized three different phenotypes. Mixed infection with a pair of phenotypically different mutants, each of which lysogenized poorly or not at all, produced a high frequency of lysogenization characteristic of infection with the wild type. The surviving bacteria were lysogenic for one or both of the infecting types of phages. Levine worked with clear plaque-forming mutants 
of P22 (A $1 b)$. He found that, when sensitive bacteria were exposed to a mixture of a virulent mutant, which of itself gave no lysogenesis, and a very weak temperate phage, which gave a very low degree of lysogenization, these two phages combined in multiple infections produced a high degree of lysogenization. These of course are true mutants with genetic deficiencies : if kept uncontaminated, they reproduce their own type indefinitely. $\beta$ particles are not mutants in this sense, as the progeny of single infection with a $\beta$ particle is a mixed brood of $\alpha$ and $\beta$ particles in the standard proportions characteristic of the parent type.

In the case of the phages listed under (2), the position is reversed. At limit dilution the percentage of $\alpha$ particles is average to high. When bacteria are exposed to higher phage concentrations, the number of lysogenized bacteria falls below, and in some cases far below, the number of available $\alpha$ particles, even when 'doubling up' is taken into consideration. This is not due to defective adsorption (Table 9). In the case of these phages, multiplicity would appear to antagonize lysogenization instead of increasing it. Whether or not this is due to the presence of a restraining component in the $\beta$ particles or to some external factor, so far unrecognized, is a question which cannot at present be answered.

The phages listed under (3) give results which are mainly in conformity with the original theory that lysogenization follows infection with a dominant $\alpha$ particle, and if no other phage types but these had been examined (the type on which the theory was based was $\mathrm{Al} a$ ) a convincing case could have been built up.

An alternative explanation of these findings which has been propounded is that each phage consists, not of a mixed population of particles with differing properties of lysogenization, but of a uniform population in which there is a certain probability that any one phage particle can give rise to a lysogenic clone: that this probability is a constant for each phage: and that the probability is doubled in a doubly infected cell, trebled in a trebly infected cell and so on. When multiplicity values are calculated according to the Poisson formula, and adjusted to the probability revealed by the percentages of lysogenesis and lysis at limit dilution, a set of theoretical figures can be constructed. The results set out in Fig. 7 show a considerable degree of agreement with these theoretical figures (much better agreement than the discarded 'dominant $\alpha$ particle' theory) but in all cases show some deviation, and in one or two cases gross deviation.

Apart from the by no means perfect fit of theoretical figures and results this hypothesis is open to criticism on at least two scores. What are the factors which determine the certain probability that any one particle can give rise to a lysogenic clone, bearing in mind that this probability varies widely in these closely related but nevertheless distinct phage types? The bacteria are prepared by standard methods, and while individual organisms may have varying characters they present the same front in all the experiments. The varying degrees of lysogenesis and lysis produced by infection with the different phage types cannot therefore be attributed to the bacteria. Before either lysis or lysogenesis occurs, the hazards of adsorption and penetration lie behind: these cannot explain the phenomenon. The 'certain probability' must therefore result from events inside each bacterium after it has been penetrated by the infective material of a phage particle. The bacteria, although they may vary individually, e.g. in age in terms of the last division, are en masse alike in all the experiments. The infective material from each phage particle, according 
to this hypothesis, is uniform for each phage type. When $\mathrm{Al} b$ is the infecting phage, an average of six out of ten of these identical units succeed in circumventing some undefined barrier, and become integrated in the bacterial chromosome: four of the ten fail to do so. In the case of A2d, only one out of ten of the invading particles reaches this goal. As all the particles in each phage are held to be alike, it follows that all, both $\mathrm{Al} b$ and A2d, are capable of producing lysogenesis. The varying number of successful lysogenizations must therefore be attributed to the chance evasion of some barrier or inhibiting mechanism within the bacterium, a chance evasion in which the different phage types have varying but consistent degrees of success. When the issues involved are examined in this way, the probability hypothesis becomes unconvincing, the more so as the existence of a mechanism capable of preventing lysogenization is speculative and its nature is undefined.

The second criticism of the probability theory lies in the fact that none of the experiments, admittedly limited in number, involving environmental changes of the bacterium-phage complex, made any significant difference to the percentages of lysogenesis or lysis.

On balance, the conception of a phage population, mixed in the sense that its members, though genetically identical, are endowed to a varying degree with some factor essential for lysogenization, is more in keeping with the available experimental evidence.

The fallacy of drawing conclusions of a general nature from the results given by a single system is heavily underlined by the results of these experiments, and, as a corollary, the necessity for widening the field of investigation is clearly demonstrated. Apart from showing that in certain cases lysogenization can result from multiple infection with $\beta$ particles, these findings are of interest mainly because they show the complexity of the multiplicity phenomenon. They provide no solution capable of general application.

The experiments with $\mathbf{A} 1 \mathbf{b}$ and A2d (Figs. 3, 6) demonstrate two other responses in bacteria exposed to very high concentrations of these temperate phages which are worthy of brief mention.

The first is a lethal response corresponding to the phenomenon which has been observed in the case of virulent phages and has been described as lysis-from-without (Andrewes \& Elford, 1932). The possibility of this reaction being produced by a weak bactericide which is lethal only when in high concentration cannot be altogether disregarded, although rendered improbable by the fact that the lethal property is removed by passing the lysate through a gradacol filter with pores sufficiently small to hold back the phage particles. The alternative explanation, a weakening of the bacterial wall by the tail-enzymes of the phage particles (Puck \& Lee, 1954) is in keeping with the accepted basis of this phenomenon in other systems.

The second is the occurrence of an increasing number of bursts, particularly in the case of Alb (Fig. 3). This observation prompted an experiment in which an established strain of Q1 (A 1 $b$ ) was exposed to a high concentration of its homologous temperate phage, A $1 b$, to which in low concentration it is immune. A number of bursts resulted. An established strain of Q1 (A2d) was then exposed to a high concentration of the heterologous temperate phage, $\mathrm{A} 1 \mathrm{~b}$, to which in low concentrations it is immune. Again a number of bursts occurred, the resulting free particles being of both types, A1b and A2d. With this evidence that a high concentration of 
temperate phage can 'induce' a lysogenic bacterium which is immune to the same phage in lower concentrations, it seems possible that the bursts under consideration arise from a two-stage process-an early lysogenization followed by induction.

With the exception of chloramphenicol, various chemical and physical agencies which have been found by other workers to affect lysogenesis have shown no specific or significant action on the systems which we have tested. Neither heat, nor cold, nor anaerobiosis, nor organic acids have had any effect other than a non-specific action attributable to interference with bacterial growth and multiplication.

\section{REFERENCES}

Adams, M. H. (1959). Bacteriophages. New York: Interscience Publishers, Inc.

Andrewes, C. H. \& Elford, W. J. (1932). The 'killing' of bacteria by bacteriophages. Brit. J. exp. Path. 13, 13.

Bertani, G. \& Nice, S. J. (1954). Studies on lysogenesis. II. The effect of temperature on the lysogenisation of Shigella dysenteriae with phage P1. J. Bact. 67, 202.

Bertani, G. (1960). On the interpretation of Boyd's 'multiplicity effect' in lysogenisation. Virology, 12, 132.

Boyd, J. S. K. (1950). The symbiotic bacteriophages of Salmonella typhimurium. J. Path. Bact. 62, 501.

Boyd, J. S. K. (1951 a). Mutation in a bacterial virus. Nature, Lond. 168, 994.

Boyd, J. S. K. $(1951 b)$. Observations on the relationship of symbiotic and lytic bacteriophage. J. Path. Bact. 63, 445.

Boyd, J. S. K. (1953). The role of mutation in the survival and multiplication of the bacterial viruses. In The Nature of Virus Multiplication. Symp. Soc. gen. Microbiol. 2, 119.

Boyd, J. S. K. (1956). Immunity of lysogenic bacteria. Nature, Lond. 178, 141.

Boyd, J. S. K. \& Bidwell, D. E. (1957). The type A phages of Salmonella typhimurium: identification by a standardized cross-immunity test. J. gen. Microbiol. 16, 217.

Hershey, A. D., Kalmanson, G. M. \& Bronfenbrenner, J. (1943). Quantitative methods in the study of phage-antiphage reaction. J. Immunol. 46, 267.

KAISER, A. D. (1957). Mutations in a temperate bacteriophage affecting its ability to lysogenise Escherichia coli. Virology, 3, 42.

Levine, M. (1957). Mutations in the temperate phage P22 and lysogeny in Salmonella. Virology, 3, 22.

LIEB, M. (1953). The establishment of lysogenicity in Escherichia coli. J. Bact. 65, 642.

LiU, P. V. (1958). Cellophane plate technique applied to the production of Bacteriophage. Amer. J. clin. Path. 29, 176.

Lwoff, A. (1953). Lysogeny. Bact. Rev. 17, 269.

Lwoff, A., Kaplan, A. S. \& Rirz, E. (1954). Recherches sur la lysogénization de Salmonella typhimurium. Ann. Inst. Pasteur, 86, 127.

Parry, W. R. \& Edwards, J. (1953). The induction of lysogenesis in Salmonella typhimurium. J. gen. Microbiol. 9, 342.

Prell, H. H. \& Prell, H. H. M. (1959). The influence of multiplicity of infection on lysogenisation in the Salmonella typhimurium system-phage P22. Arch. Mikrobiol. 34, 211.

Puck, T. T. \& LEe, H. H. (1954). Mechanism of cell wall penetration by viruses. I. An increase in host-cell permeability induced by bacteriophage infection. J. exp. Med. 99, 481. 